\title{
ASSESSMENT OF THE FINANCIAL PERFORMANCE TRANSPARENCY OF PUBLIC BENEFIT ORGANISATIONS
}

\author{
Santa Voitkane ${ }^{1}$, Ingrida Jakusonoka ${ }^{2}$ \\ 1,2 Latvia University of Life Sciences and Technologies, Jelgava, Latvia, Ingrida.Jakusonoka@llu.lv
}

\begin{abstract}
Research purpose. The aim of the research is to assess the transparency of financial performance of public benefit organisations (PBOs).

Methodology. To achieve the aim and to accomplish the tasks set, general-scientific methods were used: the monographic method, the method of document analysis and the graphical method. A statistical analysis method descriptive statistics - and a sociological research method - surveying - were used as well.

Findings. Since 1 October 2014 when the Public Benefit Organisation Law came into force in Latvia, the number of PBOs has been increasing every year. On 1 January 2018, the number of organisations with valid PBO status had reached 2,775. To get an insight into the opinions of Latvian PBOs on the disclosure of financial information, a questionnaire was developed. The survey was attended by 201 respondents. The questionnaires revealed that 64.68 percent of the respondent organisations had a website or a web page on a social network, although only 21.89 percent of these respondents' websites contained some sort of financial information. In parallel with the PBO survey, a society survey was conducted to get an overview of the public opinions about the need to make PBO financial information freely available. The survey was attended by 116 respondents. The results indicated that although the $\mathrm{PBO}$ attitude to the disclosure of financial information was considered to be reserved, the public saw the need for such information. In view of the insufficient availability of financial information in the country and the low activity of PBOs themselves in voluntarily disclosing their financial information on their websites, it is necessary to carry out activities that supplement free-access information resources and/or motivate the organisations themselves to provide free access to such information.
\end{abstract}

Practical implications. Based on the experience of other European countries, the Ministry of Finance has to consider amending the PBO Law to oblige PBOs to publish their annual financial and performance reports on their websites or in an equivalent way, thereby contributing to the transparency and accountability of the PBOs towards the society.

Key words: Public benefit organisation; Donations; Reports; Transparency.

JEL Codes: L31; M41.

\section{Introduction}

The NGO sector is appreciated both in Europe and in the whole world for its growing contribution to the development of the society and the country as well. Understanding the role of NGOs, countries seek to enhance the performance of the sector, particularly the organisations benefitting the entire society directly or indirectly, by means of various mechanisms. Public benefit status is the most widespread mechanism of this kind of support, which contributes to the performance of public benefit organisations (PBOs) through tax relief and other preferences granted. The key privilege provided by PBO status is the right to actively attract donors. Even though the status imposes restrictions on the financial performance of such organisations, the privileges granted increase the number of PBOs, which, in its turn, raises a question about the supervision sufficiency and performance transparency of the organisations as well as their openness to the society as the main supporter and beneficiary. The government and PBOs themselves have to actively care about maintaining the image of PBOs as trustful organisations, yet feedback to the society does not always occur or the information given is not always sufficient to get a complete insight into the performance of the organisations. 
The research aim is to assess the transparency of financial performance of PBOs and the opportunity of the society to get extensive, credible and essential information about the performance of PBOs.

To achieve the aim, the following specific research tasks were set:

1. To assess the legal framework and supervisory measures for PBOs

2. To examine the public availability of financial information on PBOs and identify the opinions of the society and experts about the transparency of the information.

\section{Literature Review}

PBO status is an instrument for promoting public benefit activities, which is widespread in Europe and which allows allocating part of NGO and public resources for tackling problems of national interest as well as for development. As the non-profit organisation sector expands, the issues of legitimacy of the organisations and whether the supervision system introduced by the government is sufficient to make the sector open and transparent become increasingly important.

The term transparency could be interpreted differently. According to Palmer (2013), transparency in the context of NGOs could be defined as the availability of relevant and credible information about the organisation's performance, financial situation and governance. Performance transparency is an instrument for building trust. The more transparent the performance of an organisation is, the higher the ratings of the organisation are given by the public, donors and supervisory institutions (Palmer, 2013).

In recent years, EU institutions as well as national governments made efforts to solve the NGO transparency and accountability problem by strengthening the requirement of supervisory bodies to provide transparency and the public's right to receive extensive, relevant and reliable information about NGO performance aspects (Exploring transparency and accountability..., 2011). The present research focuses on ensuring PBO transparency through reporting not only to national authorities, as stipulated by the law, but also to the public, and, as far as the authors know, the present research is the only one in Latvia that examines such aspects of PBO performance.

As the non-profit organisation sector expanded, an increasingly essential matter is the legitimacy of the organisations and whether the national supervisory systems are sufficient for ensuring the sector is open and transparent (Exploring transparency and accountability ..., 2011). However, not only information disclosure but also accountability for the content of the information and its influence on its users are important. As pointed out by T.P.Gordon et al. (Gordon et al., 2010), successful communication with stakeholders is possible through annual financial and performance reports if the reports meet five criteria: completeness, accessibility, transparency, full disclosure and relevance.

It has to be understood that the performance of a PBO, unlike that of a commercial enterprise, is not associated only with the financial performance of it. An assessment of financial performance is complicated, and it could be viewed through various dimensions. As stressed in the scientific literature, only combining quantitative and qualitative information gives an opportunity to transparently compare the social performance of a $\mathrm{PBO}$ with the resources used in order to prove the social and economic effectiveness of the PBO's activity. The key purpose of information disclosure is to build confidence in the organisation's activities, demonstrating both the organisation's competence in its field of activity and the fulfilment of its promises (Gordon et al., 2010; Dyczkowski, 2016).

Reports on PBO activities play two important roles. First, the reports guarantee the organisation's accountability towards the public and the state; second, the reports contribute to the effectiveness and usefulness of the activities (Dyczkowski, 2016). Mitchell (2014) points out that reporting is intended for informing various stakeholders about the following three issues:

1. Social impacts that the organisation has created by its disposable resources

2. Stimulating solutions to social initiatives, for example, the overall usefulness of subsidies, tax relief and tax exemptions

3. Effectiveness of the supervision procedure that prevents misappropriation of funds 
In many countries, information disclosure forms are designed in a way to build confidence in the following aspects:

- Organisation's goal and public benefits provided

- Use of property and/or funds

- Donations received and accounting for the donations

- Administrative costs and compliance with the restrictions imposed

- Economic activity, the size and role of it to achieve the goals

- Value of assets (Exploring transparency and accountability..., 2011)

Financial and performance reporting by PBOs is important not only for supervising the effectiveness and usefulness of their activities in respect to public funding spent but also for disclosing information to all the groups of stakeholders about their economic resources and achievements. The groups of stakeholders are represented not only by lawmakers and supervisory bodies but also by donors and the society as a whole (Waniak-Michalak \& Zarzycka, 2012). Gordon and others (2010) point out that effective communication with stakeholders could be done through published annual financial and performance reports if the reports meet five criteria: completeness, accessibility, transparency, full disclosure and relevance. Direct public and indirect governmental support given to PBOs imposes an obligation on the PBOs - not legislative but at least based on ethical principles - to inform the public about the organisation's activities and performance, thereby demonstrating its accountability for the funds received and spent. However, the government and/or organisations not always disclose such information to the public, which may lead to an increased mistrust of the organisations (McDowell et al. 2013). The availability of information to external users in particular not only affects the opinions of individuals on the organisation's activities but also helps to determine the effectiveness of fund collection efforts in the future, the amount of voluntary contributions and the overall level of public support to the organisation (Dyczkowski, 2016). Some donors donate their funds spontaneously, based on momentary emotions (Dyczkowski, 2015), whereas others make their decisions carefully and based on feasibility studies. The need for relevant information is particularly important when dishonest behaviour by the NGOs or even NGO fraud scandals occur. Such cases motivate donors to carefully assess which NGOs should be given some support (Gordon et al. 2010).

The website of an organisation is an instrument allowing reducing the asymmetry of information, voluntarily supplying information to any interested individual about the organisation's activities as well as demonstrating confidence and readiness for external control (Tremblay-Boire \& Prakash, 2015). In some European countries, for example, in Poland, PBOs are obliged to publish both their annual financial reports and their performance reports on their websites. However, in the countries where no such an obligation has been imposed, information disclosure or undisclosed is a free choice of the organisation. As proved by some research investigations in Europe and America, the voluntary initiative to publish a financial report or disclose other financial information is quite low (Tremblay-Boire \& Prakash, 2015; Striebing, 2017).

\section{Methodology}

To achieve the aim and to accomplish the tasks set, in this research, general-scientific methods - the monographic method, the method of document analysis and the graphical method - as well as a statistical analysis method, namely, descriptive statistics, and a sociological research method, surveying, were used.

The research used research papers by foreign authors who focused on the role of financial performance transparency of PBOs and non-profit organisations as a whole. The research analysed laws and cabinet regulations binding upon Latvian PBOs, legal documents of other European countries as well as research investigations into the NGO sector of Latvia done by the Latvian Civic Alliance. The source of statistical data on PBOs was informative materials provided by the State Revenue Service (SRS) as well as other information. 


\section{Results}

Since 1 October 2014 when the Public Benefit Organisation Law came into force in Latvia, the number of PBOs has risen, on average, by 179 organisations a year, which was a 13.94 percent annual increase. On 1 January 2018, the number of organisations with valid status of PBO had reached 2,775 (Fig. 1), which accounted for approximately 11 percent of the total number of associations, foundations and religious organisations registered with the Register of Enterprises of the Republic of Latvia.

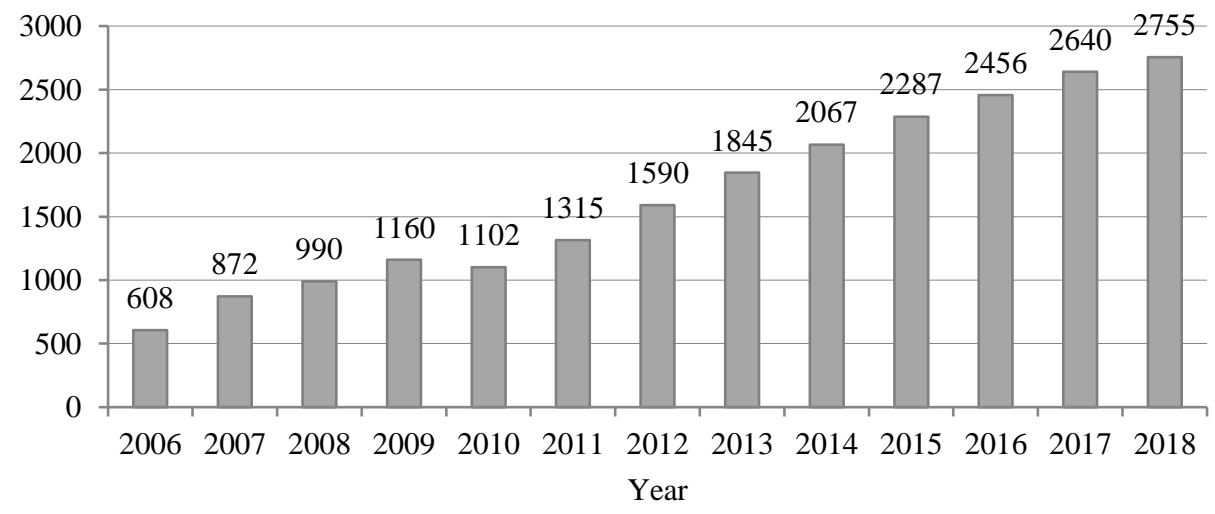

Fig. 1. Changes in the number of PBOs in Latvia in the period 2006-2018 (as on 1 January)

(Source: authors' construction based on the data of the Ministry of Finance and the State Revenue Service of the Republic of Latvia)

Achieving the goals of organisations mainly depends on available public financial assistance. Tax relief allows donors to effectively attract sponsors and hence funds. For this reason, this particular aspect is often the most important one encouraging to get PBO status (Dyczkowski, 2015). In 2015 in Latvia, according to the SRS, donations and gifts to PBOs totalled EUR 57.31 million, whereas in 2016 the total was EUR 60.57 million.

In Latvia, PBO status gives some advantages to the PBOs, yet a number of significant financial restrictions are imposed on them, which mainly relate to the donations received. If the total amount of donations received by a PBO in a calendar year exceeds 12 minimum monthly salaries or EUR 5, 160 (since 1 January 2018), such organisation has a duty to use not less than 75 percent of such total amount and revenue from their economic activities only for such field of public benefit activities, which is referred to in the decision on granting of $\mathrm{PBO}$ status to the relevant organisation. Administrative expenses, regardless of the amount of revenue, may not be more than 25 percent of general donations used in the relevant taxation period (Sabiedriskā labuma organizāciju..., 2004).

In Latvia, PBOs are supervised by the SRS in cooperation with the Public Benefit Commission, and the compliance of $\mathrm{PBO}$ activities with the law, just like it is in the majority of other European countries (Moore et al., 2008), is supervised through two major information sources - annual financial reports containing financial information and annual performance reports (previous year performance reports and future activity plans) that contain qualitative or descriptive information.

In Latvia, the Public Benefit Organisation Law does not prescribe that PBOs are obliged to disclose annual financial reports and/or performance reports on their websites or in other ways. Accordingly, the main source of information on PBOs in Latvia is the SRS Register of PBOs or a public database available on the SRS website. The database provides both current and historical information on all the organisations which have been granted and which have lost their PBO status since the PBO Law became effective. Starting with 2010, all the PBO reports - previous year performance reports and future activity plans - submitted during the status validity period are publicly available in the database. The SRS does not disclose PBO financial reports, yet the electronic copies, as prescribed by the regulations regarding annual financial reports for associations and foundations, are transferred to the Register of Enterprises 
of the Republic of Latvia not later than within 5 business days after they have been received. The Register of Enterprises, as well as Lursoft IT Ltd as a user of the reports, makes the reports available publicly (Fig. 2). Access to PBO financial information through the Register of Enterprises and Lursoft IT Ltd is not unrestricted and free of charge; the access is provided after a fee has been paid. It follows that the government does not ensure free access to PBO financial information for the public. Free access to financial information depends on the wish of PBOs themselves to implement best practice principles.

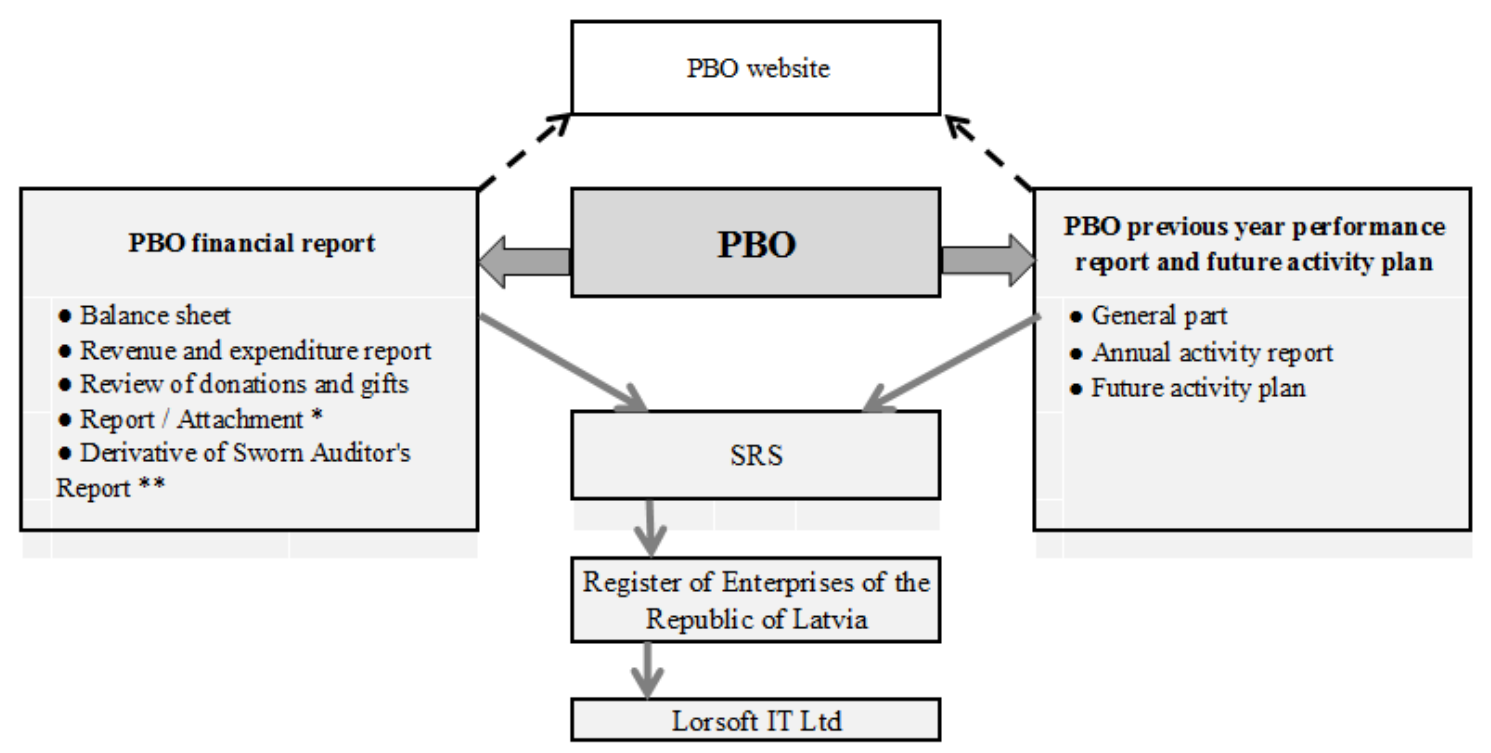

Fig. 2. Flow of PBO annual financial and performance reports

(Source: authors' construction based on analytic studies of legal acts)

In other European countries, the way of disclosing PBO financial information is completely opposite. After examining information resources, among them legal acts, pertaining to PBOs in European countries, the authors found totally five solutions to improving the transparency of PBO performance:

- National institution-maintained PBO registers, which provide both qualitative descriptive information and financial data (the United Kingdom, Ireland, Hungary). For example, in the United Kingdom, Ireland and Hungary, the governments guarantee the availability of extensive and easy-to-use PBO public registers that supply information on various performance aspects of the PBOs, as well as annual reports. The British Charity Commission that controls and ensures information disclosure makes also audited annual financial reports available in addition to the basic information (goal, target audience, address, contact details, total annual revenue and expenditure by year, founders, etc.) provided by the Register of Charity Organisations if the revenue of the organisation exceeds GBP 25, 000 or approximately EUR 28,600. It should be added that the database allows performing analyses of the sector by size and kind of revenue and by other variables (Find charities, [s.a.]). Such databases help the public, donors and other users of information to make informed decisions about which charity organisations they wish to fund and to support by voluntary work or the services of which organisations they wish to buy. The practice of disclosing information in the mentioned countries is a good example.

- Binding legal acts prescribe PBOs to publish their annual financial and performance reports (Poland, Croatia, the Netherlands, Hungary). For example, Section 4b and Paragraphs 1a and 2a of Section 23 of the Public benefit and Voluntary Work Law of the Republic of Poland prescribe that PBOs are obliged to make their annual financial and performance reports available, including on their websites (Ustawa o działalności pożytku..., 2003). Similar legal provisions are included in CLXXV law of Hungary on the rights to unite, public benefit status and NGO performance and support (2011); Paragraph 4 of Section 30 of the law provides that organisations have to publish their annual financial and performance reports if they have their own websites. In addition, the law requires that NGOs have 
to make the information available until data for the next calendar year are disclosed (2011. évi CLXXV..., 2011).

- PBOs are obliged to publish their annual financial reports in the official newspaper (France). The legislation of France prescribes that associations and foundations that have received more than EUR 153, 000 in donations and/or subsidies in the reporting year are obliged to publish their financial reports in the Journal Officiel des Associations et Fondations d'Entreprise (Association reconnue d'utilité..., [s.a.]), which is actually similar to the official newspaper 'Latvijas Vēstnesis' issued in Latvia.

- The NGO sector establishes and maintains a PBO/NGO sector organisation database with extensive financial information about the organisations (Italy, Spain). For example, PBOs in Italy have an opportunity to create the organisation's profile in the portal 'Italia non profit'. The technical capabilities of the portal allow depicting the information placed in an attractive and easy-to-perceive way - basic information, activities done and financial information. Such a solution is an excellent opportunity for the organisations having no resources for creating and maintaining their own websites. The portal allows its users to select organisations by various criteria as well as compare the organisations.

- The PBO database with the 'trust mark'. The Czech PBO Association has created a database only for the organisations that have acquired a trust mark. The trust mark 'Spolehlivá veřejně prospěšná organizace', which translates as a trustful PBO, was created in Czechia as a response to the demands of the public and the organisations themselves for transparency. The purpose of the trust mark is to inform potential supporters and the society as a whole that PBOs properly and transparently manage their entrusted resources to achieve the goals set (O značce [s.a.]). The concept of such a mark acts both as a self-control instrument and as a demonstration to the public of responsible operational practices. Undoubtedly, such a demonstration also allows competing against other NGOs; yet at the same time, because of the cost incurred, it is available to the organisations being able to invest in acquiring such a mark.

To get insight into the opinions of Latvian PBOs on financial information disclosure as well as national supervisory requirements regarding the PBOs, a questionnaire was designed by the authors. The questionnaire included 14 questions that could be divided into 3 groups: basic facts of the organisation; assessment of the supervisory mechanism for PBOs; attitude of PBOs to the disclosure of their financial information. The questionnaire was designed in electronic format by using Google Forms. E-mails with a request to participate in the survey and a link to the electronic address of the survey was sent to as many as 1,610 PBOs; however, given the fact that 42 e-mail addresses were inactive, the questionnaire was sent to totally 1,568 PBOs, which accounted for 56.50 percent of the total number of PBOs in Latvia as on 1 January 2018. The request e-mails were sent periodically, from 28 February to 21 March 2018. The PBO e-mail addresses were acquired from the PBO database. The selection of potential respondents was based on a randomised list of PBOs (MS Excel function 'Rand()').

Responders to the request to participate in the survey totalled 201, of which 66.67 percent were organisations with 5 or more years of experience in having PBO status.
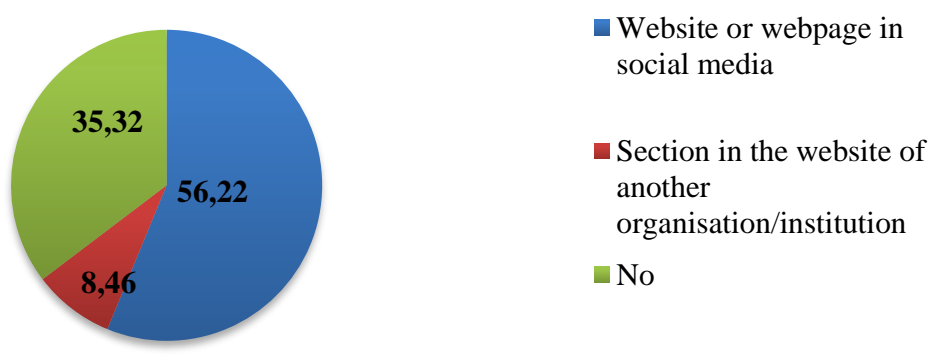

Fig. 3. Percentage breakdown of respondent replies to the question about whether the organisation has a website (Source: authors' construction based on PBO survey data, $n=201$ ) 
An affirmative reply to the question of whether the organisation had a website or a web page in social media was given by 64.68 percent of the respondents (Fig. 3). Among these respondents, 113 (56.22 percent of the total) had a website or a web page in social media and 17 (8.46 percent) had a section in the official website of another organisation or institution. This means that 130 organisations had an opportunity to inform the public about their activities and related matters. However, $71 \mathrm{did}$ not have such an opportunity (Fig. 4). An analysis of the questionnaires returned by the organisations of this group revealed that 50 (70.42 percent) had acquired their PBO status in the period from 2005 to 2012. This means that these particular organisations did not make it possible to familiarise the public with their activities, even though they operated for more than 5 years, especially in view of the fact that 38 of the organisations declared donations as one of the key sources of revenue.

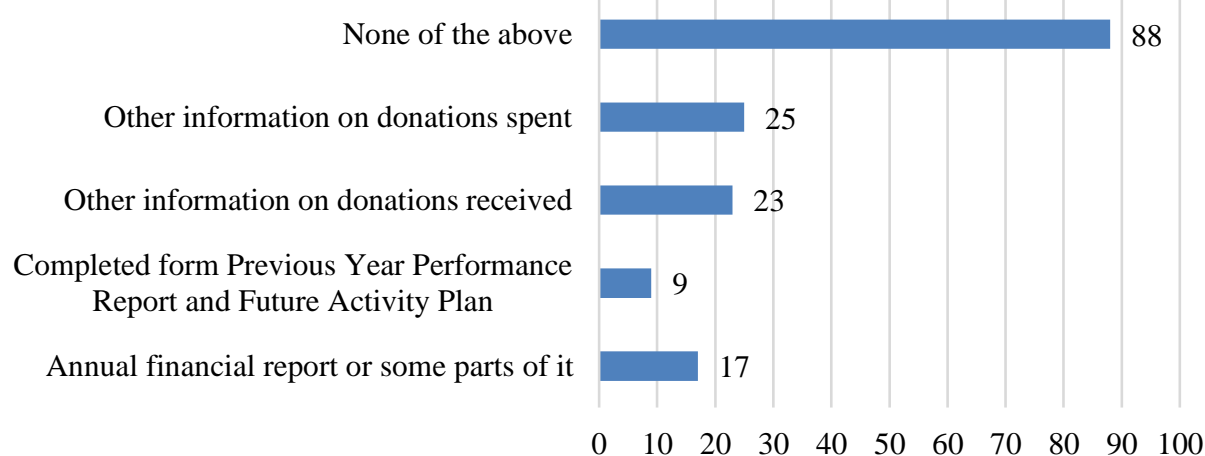

Fig. 4. Breakdown of the respondent organisations by type of information available on their websites (Source: authors' construction based on the survey of PBOs, $n=130$ )

The respondents who gave an affirmative reply to the above-mentioned question were requested to indicate whether their websites had some of the kinds of information presented in Figure 5. Of the 130 respondent organisations, 88 (67.69 percent) did not disclose information of any of the mentioned kinds (Fig. 5). This group included 12 out of 17 organisations that indicated they had a section in the website of another organisation. The authors suppose that some of the organisations did not place their financial reports and completed forms because of potential content restrictions and/or due to the lack of technical possibilities. The reasons why the remaining 118 organisations chose to disclose neither their financial nor performance reports should be associated with their notions rather than technical barriers. According to the survey, only 44 (21.89 percent) respondent organisations placed some of the mentioned four kinds of information on their websites. Most of them were those that chose to place on their websites not their officially approved annual financial or performance reports but self-prepared financial information about donations received (17.69 percent) and/or spent (19.23 percent) (Fig. 5).

Most respondents, totally 87 or 43.28 percent of the total, had doubts as to whether they needed to disclose their financial performance information to the public when asked whether their organisations would make their financial performance information available with pleasure, thereby exercising a best practice. An affirmative reply regarding the wish to disclose their financial performance information was given by 80 (39.80 percent), whereas a negative reply was made by 34 (16.92 percent) of the respondents. The results indicated that most of the organisations wished to provide financial information or at least considered such an option.

The last question in the questionnaire familiarised the respondents with the fact that in other European countries such as Estonia, the United Kingdom, Ireland and Hungary, PBO annual financial reports or their parts are also published on national institution websites. The respondents were asked whether, in their opinion, the SRS of Latvia too should make not only performance reports but also financial reports or parts of them available publicly. An analysis of the replies revealed that 55.22 percent of the respondents were not quite sure and chose the reply option 'maybe'. A negative reply was given by 27.36 percent, whereas an affirmative reply was given by only 17.41 percent of the respondents. The survey results implied that most of the PBOs viewed financial reporting with caution and were not 
convinced of the need for such a practice. Such a response does not make sense, as all the annual financial reports are available on the websites of both the Register of Enterprises and Lursoft IT Ltd where anyone may view them for a fee. In this case, the question is whether the public has to be given a possibility to view such information without any restriction and free of charge.

An explanation of such an attitude should be sought in the management of an organisation - the professionalism of the management. Examining the circumstances under which organisations voluntarily choose to disclose their financial information, Striebing (2017) found that the wish of an organisation to voluntarily disclose its financial information might be explained by the professionalism of the organisation's management and stressed the role of a management comprehending and supporting the principles of professionalism and best practices.

Because the number of respondents was small, that is, only 57.43 percent of the minimum representative sample size, the results of the survey did not statistically represent the situation in the entire PBO group. Assuming that the total number of PBOs was 2,775 $(N)$, at the significance level of $0.05(e)$, it was required to survey at least $350(n) \mathrm{PBO}$ representatives in order to get representative data $\left(n=N /\left(1+N^{*}(e)^{2}\right)\right)$ (Israel, 1992). Even though the small number of PBO representatives did not allow identifying the overall situation, the authors supposed that there was a low probability that the overall situation might be considerably different. The relevant legal framework does not require PBOs having PBO status to report to the public on the aspects of their performance. For this reason, if a PBO is not ultimately dependent on public support, feedback from the public might be considered unnecessary by the PBO. In the authors' opinion, comprehensively reporting to the public on their progress and performance is not among the best practices of PBOs, and it is likely that most of the PBOs do not understand the need for it.

To identify how many Latvian PBOs had websites or web pages in social media, the authors examined all the performance reports for 2016 or 2015, available in the SRS PBO database, of the organisations having the status of PBO as on 1 January 2018. As of this date, totally 2,775 organisations had valid PBO status, but reports had been submitted by 2,536 organisations. Totally 991 organisations had specified their addresses in the general information (contact detail) section of their reports or on their websites or web pages in social media, accounting for 39.08 percent of the total number of the organisations examined. According to the results, the SRS PBO register and the performance reports available in the database were probably the only source of information on more than half of the PBOs. It is understandable that not all PBOs are financially secure enough to afford to create and maintain a website; besides, the scope of their activity is not broad enough to consider it necessary. At the same time, broad free-of-charge opportunities are provided by social media that can serve as free-access information platforms. The examination of PBO performance reports revealed that 48 PBOs or about 2 percent of the total number of the PBOs examined had specified their web page addresses created in social media. However, in view of the fact that it is required to specify the web page address in the form and that there is broad scope for interpretation whether a website and a web page in social media are the same thing, this indicator value was probably higher.

To identify how many PBOs having websites preferred publishing their annual financial reports or some parts of the reports, their performance reports and/or other financial information, the authors examined 300 PBO websites. The number of the websites examined made up 30.27 percent of the total websites identified. The website addresses were acquired from the above-mentioned examination of PBO performance reports. In view of the limited technical possibilities of social media, the social media addresses were not included in the list of website addresses prepared for the website examination. The list was randomised (MS Excel function 'Rand()'), and the first 300 addresses were examined. However, in view of the fact that 32 addresses were inactive, 32 other addresses were examined to acquire the initially planned data sample. The relatively large number of inactive website addresses indicated that the total number of PBO websites determined initially was actually smaller.

When examining the PBO websites, the authors identified whether a website had any of the following information: a balance sheet, a revenue and expenditure statement, a review of donations and gifts, a table headlined 'Detailed information on donations and gifts spent', an annual financial report, other financial information, a performance report for the previous year and a plan for future activities. 


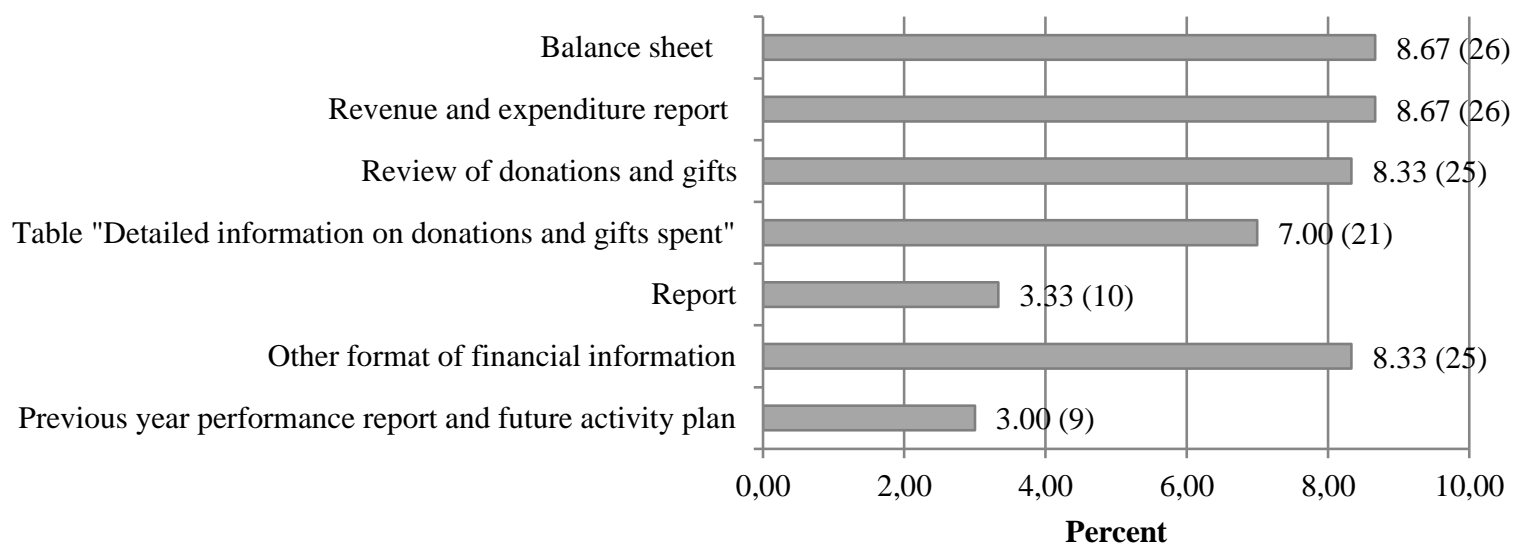

Fig. 5. Types of information available on PBO websites, percent and number

(Source: authors' construction based on a study of 300 PBO websites)

The examination of PBO websites allowed concluding that most or 85.33 percent of the websites examined did not contain any of the information sought. This means that only 14.67 percent or 44 of the PBOs examined had voluntarily placed their annual reports or self-produced, selected financial information on their websites. Most often, a balance sheet, a revenue and expenditure statement and other financial information were available on the websites - each of them could be found on the websites of 26 PBOs. Annual financial reports (10 PBOs) and annual performance reports (9 PBOs) were available least often (Fig. 5).

The number of the websites examined was representative and could give insight into the overall situation and the trend in the provision of information on the PBO websites. The PBO initiative in the disclosure of their financial information could be rated as low.

To get insight into the opinions of the public as the recipient of PBO services and the PBO supporter about the need to make PBO financial information freely accessible, a survey of the public was conducted in parallel with the survey of PBOs. The survey, just like that of PBOs, was conducted from 28 February to 21 March 2018. The questionnaire was designed in electronic format and, together with a request to participate in the survey, was distributed in social media. The questionnaire contained 11 questions, of which 3 requested to specify gender, age and education.

In view of the fact that the term PBO is not frequently used in the public arena and instead the following ones are more often referred to: a charity organisation, an association and a foundation, the questionnaire provided a simple definition for a $\mathrm{PBO}$.

When the survey was over, 116 respondents, of which 80 (68.97 percent) were women and 36 (31.03 percent) were men, had submitted their replies. The age structure of the respondents revealed that the percentage of those aged 25 to 40 was the highest, accounting for 57.56 percent of the total. The second largest group was those aged 41 to $60-36.21$ percent. Of the respondents, 56.03 percent had higher education and 36.21 percent had secondary professional education.

Among the respondents, 90 or 77.59 percent had given some support to a PBO. Based on this fact, one could assume that 77.59 percent respondents could have a strong wish to be familiarised with PBO performance. Of the total respondents, 48 or 41.38 percent replied affirmatively to a question whether they had examined publicly available information on the performance of some PBO. Of this group, 42 supported some PBO activities. This indicates that less than half of the respondents who were really engaged in achieving PBO goals (46.67 percent) were interested in information on the progress and performance of the PBOs. The fact that not every PBO supporter followed relevant developments is a usual phenomenon being described in the scientific literature (Dyczkowski, 2015; McDowell et al. 2013; Palmer, 2013). It could be explained by their trust in PBOs and/or their spontaneous, emotion-based actions that are not followed by any further interest in the PBOs. 
The respondents who noted that they had examined relevant information were requested to specify the particular information sources they used. Of the reply options provided in the questionnaire, the most frequent reply was PBO websites, which was given by 66.67 percent of the total respondents of this group. Besides, the respondents acquired information from other websites providing the information on the PBOs they were interested in -31.25 percent of the total respondents of this group. It has to be mentioned that only six respondents indicated annual financial reports as an information source used. This small respondent number might be explained by a number of reasons; the main ones are as follows: unavailability of financial reports and a lack of knowledge of how to analyse financial information, which do not make a wish to get acquainted with such information.

The respondents were asked whether they would be interested in PBO financial information, referring to data on donations spent as an example; 44 (37.93 percent) answered 'yes'. However, 39 (33.62 percent) of the respondents noted that they were not interested in such information, and the remaining ones - a similar proportion - indicated they could be potentially interested in it. The similar proportions of the replies indicated that the prevalence of interested individuals was unconvincing. Nevertheless, the reply 'maybe' should not be viewed as negative, and one can assume that, of the total respondents, 66.38 percent would wish to see or at least considered an opportunity to see PBO financial information.

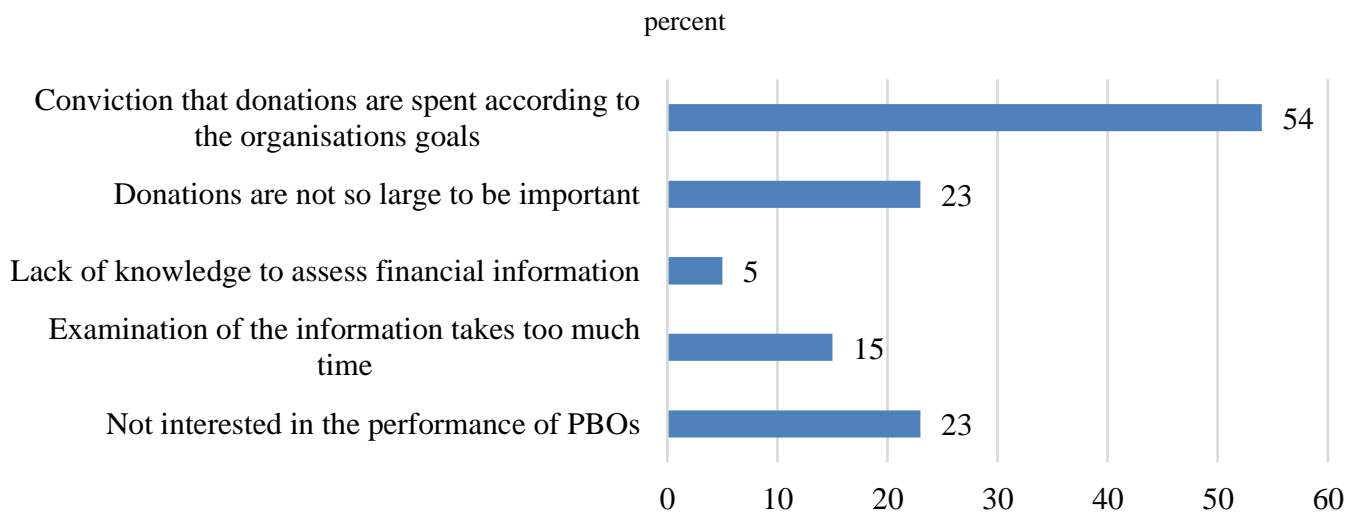

Fig. 6. Reasons of not using financial information by the respondents (Source: authors' construction based on survey data, $n=39$ )

The respondents who indicated they did not use financial information were requested to reveal the reasons for it. Of the total 39 respondents, 54 percent indicated they trusted in the organisations and therefore did not see a need to get insight into this kind of information. The second most frequent reply was the fact that the financial assistance provided was not so significant and, therefore, it was not important to get insight into the performance aspects of the organisation; such a reply was given by nine respondents (Fig. 6). The same number of respondents replied they were not interested in the performance of PBOs. Totally, seven respondents gave two or more answers.

The questionnaire requested the respondents to indicate whether, in their opinion, data on donations received and spent have to be publicly available. The survey revealed that 92 respondents (79.31 percent of the total 116 respondents) indicated that, in their opinion, such information had to be freely available. A negative reply was given by 7 respondents or 6.03 percent of the total respondents. The rest of the respondents were not sure and chose the reply 'do not know'. The proportion of affirmative replies convincingly shows that most of the respondents believed that such information had to be freely available, which was consistent with the authors' opinion.

\section{Conclusions}

In Latvia, the financial performance of PBOs is considered to be formally transparent, relying on the initiative of the PBOs themselves to disclose their financial information. In contrast, in other European countries, the situation with the public availability of PBO financial information is considerably better in relation to its users, as solutions are found as to how to make the information freely available. 
PBOs in Latvia view financial reporting with caution, and in most cases they are not convinced of the need for disclosing their financial information in detail.

The examination of PBO websites by the authors allowed concluding that less than half of the total PBOs had a website or web page in social media. However, the PBOs that had a website, thereby communicating with the public, preferred not to make their financial reports or some parts of the reports, their performance reports or other financial information publicly available. For this reason, the PBO initiative in the disclosure of their financial information could be rated as low.

However, the public as the recipient of PBO services and the PBO supporter believe that such information has to be freely available, even though the interest in it is not unambiguous.

In view of the insufficient availability of financial information in the country and the low activity of PBOs themselves in voluntarily disclosing their financial information on their websites, it is necessary to carry out activities that either supplement free-access information resources and/or motivate the organisations themselves to provide free access to such information.

The Civic Alliance of Latvia should take steps aimed at educating PBOs, popularising and explaining the role of feedback as well as best practices as a component needed to build the trust of the public in the PBOs.

In view of the practices of other European countries, the Ministry of Finance has to consider the need to incorporate a requirement into the $\mathrm{PBO}$ Law for $\mathrm{PBO}$ s to disclose their annual financial and performance reports on their websites or in another similar way, thereby contributing to the transparency and accountability of PBOs towards the public.

\section{References}

Association reconnue d'utilité publique, Ministère de l'éducation nationale [Accessed 18.02.2018]. Available from Internet <http://www.associations.gouv.fr/reconnaissance-d-utilite-publique.html>

Dyczkowski, T. (2015). Financial and non-financial information in performance assessment of public benefit organizations. Research Papers of the Wroclaw University of Economics, vol. 398, 134-145.

Dyczkowski, T. (2016). Applying Text Mining to Analyze the Performance of PBOs on the Basis of Their Obligatory Annual Activity Statements. Problemy Zarzadzania, vol. 14.

Exploring transparency and accountability regulation of public-benefit foundations in Europe. 2011. European Foundation Centre [Accessed 14.02.2018]. Available from Internet <http://efc.issuelab.org/resource/exploringtransparency-and-accountability-regulation-of-public-benefit-foundations-in-europe.html>

Find charities [Accessed 15.02.2018]: Charity commission for England and Wales. Available from Internet <http://apps.charitycommission.gov.uk/Showcharity/RegisterOfCharities/registerhomepage.aspx>

Gordon, T. P.; Khumawala, S. B.; Kraut, M.; Neely, D. G. (2010). Five dimensions of effectiveness for nonprofit annual reports. Nonprofit Management and Leadership, vol. 21 (2), 209-228.

Israel, G.D (1992). Determining Sample Size. Fact Sheet PEOD-6. University of Florida, Florida Cooperative Extension Service [Accessed 25.02.2018]. Available from Internet < http://www.academia.edu/21353552/Determining_Sample_Size_1 >

Palmer, P. D. (2013) Exploring attitudes to financial reporting in the Australian not-for-profit sector. Accounting \& Finance, vol. 53 (1), 217-241.

Reliable Public Benefit Organization [Accessed 25.02.2018]: Spolehlivá veřejně prospěšná organizace. Available from Internet <https://www.znackaspolehlivosti.cz/reliable-public-benefit-organization/>

Mcdowell, E. A.; LI, W.; Smith, P. C. (2013). An experimental examination of individual donors' information needs and use. Financial Accountability \& Management, vol. 29 (3), 327-347.

Mitchell, G. E. (2014). Creating a philanthropic marketplace through accounting, disclosure, and intermediation. Public Performance \& Management Review, vol. 38 (1), 23-47. 
Moore, D.; Hadzi-Miceva, K.; Bullain, N. (2008). A Comparative overview of Public Benefit Status in Europe. The International Journal of Not-for-Profit Law, vol 11 (1).

Sabiedriskā labuma organizāciju likums, 2004. gada 17.jūnijs (Public benefit Organisation Law. 17 June 2004). 07.07.2004, no. 106 (3054) Latvijas Vēstnesis [Accessed 19.01.2019]. Available from Internet <https://www.vestnesis.lv/ta/id/90822-sabiedriska-labuma-organizaciju-likums>

Statistika par sabiedriskā labuma organizāciju statusa piešḳiršanu un uzraudzību līdz 2017. gada 31.decembrim (Statistics on granting and supervision of the status of public benefit organisation up to 31 December 2017). 2018. VID [Accessed 20.03.2019]. Available from <https://www.vid.gov.lv/sites/default/files/slo_statistika_lidz_2018.pdf>

Striebing, C. (2017). Professionalization and Voluntary Transparency Practices in Nonprofit Organizations. Nonprofit Management and Leadership, vol. 28 (1), 65-83.

Tremblay-Boire, J., Prakash, A. (2015). Accountability. org: Online disclosures by US nonprofits. International Journal of Voluntary and Nonprofit Organizations, vol. 26(2), 693-719.

Ustawa o działalności pożytku publicznego i o wolontariacie, 2003, LexLege [Accessed 18.02.2018].. Available from Internet <https://www.lexlege.pl/ustawa-o-dzialalnosci-pozytku-publicznego-i-o-wolontariacie/\#ustawa-odzialalnosci-pozytku-publicznego-i-o-wolontariacie/>

Waniak-Michalak, H., Zarzycka, E. (2012). Performance measurement of public benefit organizations on the basis of information from financial statements and its influence on their results. Zeszyty Teoretyczne Rachunkowości, vol. 68 (124), 147-160.

2011. évi CLXXV. törvény az egyesülési jogról, a közhasznú jogállásról, valamint a civil szervezetek müködéséről és támogatásáról, 05.12.2011, Wolters Kluwer [Accessed 18.02.2018]. Available from Internet https://net.jogtar.hu/jogszabaly?docid=A1100175.TV 